\title{
Effect of soil and environment on winter vegetables production
}

\begin{abstract}
The main purpose of this study is to explore the effects of soil and environment on winter vegetable production. It also explores the factors of soil and environment responsible for yield variation of winter vegetables. This study is a qualitative study which uses a number of secondary sources including journal articles, books, scientific magazines, statistical data and internet sources. This study reveals that there is a great impact of soil and environment on winter vegetable productions. It also explores that a number of edaphic factors like soil type, soil $\mathrm{pH}$, soil fertility, and soil salinity and environmental factors like light, temperature, humidity, drought and flooding are responsible for the variation of the yield of winter vegetable production. This article suggests that a consciousness and knowledge dissemination is necessary to the farmer's level about the effects of soil and environmental factors for maximum yield of winter vegetables.
\end{abstract}

Keywords: soil, environment, winter vegetables, production, edaphic factor, yield
Volume 6 Issue 4 - 2018

\author{
AZM Shafiullah Prodhan,' Md Shahidul \\ Islam, ${ }^{2}$ Md Mydul Islam, ${ }^{3}$ Md Nazmul Haque, ${ }^{4}$ \\ Monirul Islam, 5,6 \\ 'Department of Horticulture, Bangabandhu Sheikh Mujibur \\ Rahman Agricultural University, Bangladesh \\ ${ }^{2}$ Department of Plant Pathology, Yunnan Agricultural University, \\ China \\ ${ }^{3}$ Interdisciplinary Center for Food Security, Bangladesh \\ Agricultural University, Bangladesh \\ ${ }^{4}$ Department of Horticulture, Bangladesh Agricultural University, \\ Bangladesh \\ ${ }^{5}$ School of Food Science and Technology, Jiangnan University, \\ China \\ ${ }^{6}$ Rural Development Academy, Bangladesh
}

\begin{abstract}
Correspondence: AZM Shafiullah Prodhan, Master student Department of Horticulture, Bangabandhu Sheikh Mujibur Rahman Agricultural University, Gazipur, Bangladesh, Tel 880176170042,Email scholarzone.cn@yahoo.com
\end{abstract}

Received: July 30, 2018 | Published: August 06, 2018

\section{Introduction}

Soil and environment is the major part of crop production. Vegetables need good soil and environment for better production. ${ }^{1}$ Mainly vegetable produce in winter but all over the season vegetables can grow. In vegetables, production depends on soil and environment. ${ }^{2}$ In soil PH, soil moisture, soil humidity, soil texture, and soil fertility are the needs for good vegetables. ${ }^{3}$ Other than temperature, rainfall, humidity, and light intensity are also need for vegetable production. Mainly vegetable production depends on the environment. ${ }^{4}$ Generally, Bangladesh has six seasons viz. Grisma (Summer), Barsa (Rainy), Sarat (Autumn), Hemanta (Late Autumn), Shhit (Winter), And Basanta (Spring). In Bangladesh, vegetables produced in mainly to two seasons such as winter and summer. Winter seasons are the major seasons for vegetable production in Bangladesh. ${ }^{5}$ In Bangladesh, $70 \%$ vegetables can grow in winter seasons such as Cole crop, brinjal, tomato, and different types of leafy vegetables. ${ }^{6}$ It needs a low temperature below than $20^{\circ} \mathrm{C}$. Winter season called vegetable seasons in our country. ${ }^{7}$ All vegetables cannot grow in all regions in Bangladesh. It depends on soil types such as potato can grow in the north part of the region such as Thakurgon, Rangpur, Bogra, and south part Munsigonj. This soil and environment are good for better potato production. ${ }^{7}$ Maximum Cole crop grown in the north part of our country because of the environment is better for Cole vegetable production. Saline soil is not suitable for vegetable production. The vegetable cannot tolerant high rainfall, saline soil, and high temperature. According to statistics, a maximum natural hazard in Bangladesh occurred in April to September in the summer seasons. ${ }^{7}$ Humidity and temperatures in this season are higher than the winter season. Flood decreases the production area in summer seasons. ${ }^{8}$ Vegetable forms a group of specialized crops. They are important economically and from a health point of view. They fit well in most farming systems as their maturity period from planting to harvest is short. ${ }^{9}$ With the ever-increasing human population, vegetables have played an important role in our national economy. ${ }^{10}$ Vegetables provide maximum output and more income per unit area of land to small-scale farmers, particularly when compared to cereals. ${ }^{11} \mathrm{~A}$ wide range of vegetables are grown in Bangladesh. ${ }^{12}$ The summer vegetables are mostly indigenous whereas most of the winter vegetables are of European origin. Production of vegetables in the cool season is hazard free and blessed with a favourable climate. ${ }^{13}$ During summer, vegetable production is affected by the flood, cyclones, and other factors associated with high temperature, humidity and rainfall. ${ }^{1}$ At present, vegetables are grown in about 4.52 lac hectares of land with a total production of 30.8 lac metrictons. ${ }^{7}$ Vegetable production in Bangladesh is far below requirement. BARI and other organization have developed a good number of HYV of different vegetable crops including improved production technology. ${ }^{6}$ If farmers use these technologies then internal requirement will be met up even we can export some vegetables abroad. The most important vegetables are winter vegetables. ${ }^{7}$ Relations of soil and environment conditions are essential for winter vegetable productions. Different types of soil present in our country in the different region. ${ }^{14}$ Winter season also called Rabi seasons. Rabi season start from October and last week of April. In this season, temperature varies from 10 to $21^{\circ} \mathrm{C}$. The main purpose of this study is to explore the responsible factors of soil and environment for yield variation of winter vegetables.

\section{Methodology}

This study is a qualitative study which uses a number of statistics for exploring the effect of factors of soil and environment on winter vegetable productions. This study is conducted based on secondary data. This study has been consulted about 51 scientific articles searched from the web of science, science direct, google scholar and springer 
link and environmental and edaphic factor data from Bangladesh Bureau of Statistics 2012 and 2015. Finally, it has consulted with a number of websites which bearing soil and environment-related study, especially for winter vegetable production.

\section{Review of literature}

Bangladesh has been striving for the rapid development of its economy. Economic development in Bangladesh could not be achieved unless a breakthrough is achieved in the agricultural sector. ${ }^{6}$ The overall contribution of the agriculture sector is 16.33 percent to Gross Domestic Product (GDP) at the current price. ${ }^{7}$ Agriculture, the main occupation of the people, witnessed a growth rate of $2.1 \%$ per annum with $47.35 \%$ of the total labour force engaged in agriculture. ${ }^{7}$ Its total food grain and vegetable production are 375.08 lakh Metric Ton (MT) per year. ${ }^{15}$ Furthermore, the export of agricultural commodities such as frozen food, tea, raw jute and others covered about $7.49 \%$ of the total earnings..$^{15}$ Though there is a trend of transformation of the share of agricultural and industrial sector over the last two decades, the share of service sector remained constant for the same period except for minor year to year variation. ${ }^{3}$ The agricultural sector contributed $33 \%$ to GDP at the beginning of the eighties which reduced gradually to $29 \%$ in $1990-91$ and $25 \%$ in $2000-01 .^{7}$ This share stands at $20.87 \%$ in $2007-08$ and $18.70 \%$ in $2012-13$ and $16.33 \%$ in $2013-14 .{ }^{6}$ The industry sector contributes $17 \%$ to the gross domestic product at the beginning of the eighties which reduces gradually to $21 \%$ in $1990-91$ and $26 \%$ in $2000-01$. This share is about $29.66 \%$ in $2007-08$ and $31.98 \%$ in 2012-13. ${ }^{7}$ The growth and stability of the economy of Bangladesh primarily depend largely on the growth of agriculture. About $75 \%$ of the total population live in rural areas and are directly or indirectly engaged in a wide range of agricultural activities. ${ }^{12}$ The agricultural sector comprises crops, forests, fisheries, and livestock. Vegetable crops are attractive because:

i. They are labor intensive cash crops.

ii. They are considered more profitable than staple crops and less risky as compared to the production of pulses and mustard.

iii. They have relatively short production cycles as compared to many field crops.

iv. They are suitable in some high land areas, particularly after irrigation has become available; available.

v. They serve social purposes, occasionally given away as gifts to visiting neighbors. ${ }^{16}$

But above all the demand for vegetables has been increasing, while demand for other crops, such as jute has declined. Vegetable sub-sector can play an important role to solve these problems in the shortest possible time. Here the importance of vegetable can be realized from two standpoints such as economic point of view and nutritional point of view. ${ }^{17}$ They provide dietary fibre necessary for digestion and health and combating malnutrition, curing nutritional disorders and diseases like anaemia, blindness, scurvy, and goitre. ${ }^{18}$ Statistics over the past decade shows a nearly 25 percent increase in the consumption of fruits and vegetables between the years 2000 and 2010. However, the average per capita fruit and vegetable consumption in 2010 was still low: $211 \mathrm{~g} / \mathrm{capita} \mathrm{day}^{7}$ compared the desirable intake of $400 \mathrm{~g} /$ capita/day recommended by WHO and FAO. ${ }^{6}$ Bangladesh has three distinct production seasons: Rabi or winter season (November to February); Kharif-1 or summer season (March to June) and Kharif-2 or wet/rainy season (July to October). The main season for vegetable production is Rabi, which is dry and cool when due to the availability of large land areas and irrigation, farmers produce vegetables, pulses and oilseeds. ${ }^{19}$ This is followed by summer when summer varieties of vegetables are produced. The varieties of vegetables produced during the wet season are small and limited to raised homesteads, high land and floating beds. ${ }^{17,20}$ The price of vegetables goes up mostly during this season due to a shortage of supply. ${ }^{21}$ Production during the summer season in recent times has substantially gone up compared to that in the 1980s because of hybrid varieties of vegetables. ${ }^{12,22}$ This has been possible due to remarkable advancement in seed technology and modern farm management.

\section{Result and discussion}

\section{Vegetables growing seasons}

In Bangladesh, vegetables are grown in two seasons such as Kharif (summer) and Rabi (winter), it depends on soil and environment. Cucurbitaceous vegetables are mainly grown in summer seasons and cruciferous vegetables are grown in winter seasons (Table 1).

Table I Seasonal vegetables

\begin{tabular}{ll}
\hline Seasons & Example of vegetables \\
\hline Rabi & Rabi Brinjal, Cauliflower, Cabbage, Broccoli, Carrot, Radish, \\
season & $\begin{array}{l}\text { Bean, Onion, Garlic, Chili, Red Amaranth, Potato, Rabi } \\
\text { Pumpkin, Bengal Spinach, and other winter vegetables. }\end{array}$ \\
\hline
\end{tabular}

Source: ${ }^{7}$

\section{Vegetable production area}

In Bangladesh, the major portion of the cultivated land is covered by rice, wheat and maize. Vegetables are cultivated small area compared to rice wheat and maize grown area. Total land is covered by winter vegetables like 12.13 portions by Brinjal, 6.95 by Pumpkin, 7.17 by Radish, 6.95 by Tomato, 4.63 by Bean, 4.41 by Cauliflower, and 57.21 by others vegetables. ${ }^{15}$

\section{Soil textural conditions for vegetables}

Soil types refer to the physical composition or properties of the soil. Soil basically consist of mineral and decompose organic matter. ${ }^{23}$ Optimum vegetables can produce in well-drained sandy loam soil. Although winter vegetable can be grown on a wide range of soil types, they are not well adapted to heavy clay soil types but every texture has some common constraints for vegetable cultivation (Table 2)..$^{24-27}$

Table 2 Soil constraints associated with soil texture

\begin{tabular}{ll}
\hline Soil texture type & Common constraints \\
\hline & $\begin{array}{l}\text { Low water-holding capacity. Seedlings can wilt } \\
\text { because of a rapidly drying soil surface } \\
\text { Low nutrient retention. Excessive leaching of } \\
\text { nutrients (particularly nitrate, potassium and } \\
\text { sulphate) } \\
\text { Acidity }\end{array}$ \\
Sandy soil & $\begin{array}{l}\text { Extremely low phosphorus fixation } \\
\text { Low organic matter content. }\end{array}$ \\
& Excessive/prolonged wetness \\
Clayey Soil & $\begin{array}{l}\text { Prone to compaction } \\
\text { Hard-setting/surface sealing if the texture is fine } \\
\text { sandy loam or silty loam } \\
\text { Prone to compaction }\end{array}$ \\
\end{tabular}

Source: ${ }^{26-28}$ 


\section{Land type classes of Bangladesh}

In Bangladesh, mainland type is medium high land, but it contains different types of land such as hilly land, high land, medium low land, low land, very low land. Winter vegetables grew well in medium high land and medium low land with well drainage condition. ${ }^{28}$ It cannot tolerate waterlogged conditions, that's why it cannot grow well in low land and very low land. ${ }^{29}$ In Chittagong $41 \%$ land covered by hill, 4\% HL, 23\% MHL, 8\% MLL; in Barisal division 2\% HL, 5\% MHL, $5 \% \mathrm{MLL}$; in Rangpur 39\% HL, 40\% MHL, 5\% MLL; in Sylhet $11 \%$ Hill, 6\%HL, 20\% MHL, 19\% MLL (Table 3).

Table 3 Land types classes of Bangladesh in different divisions

\begin{tabular}{lllllllll}
\hline \multirow{2}{*}{$\begin{array}{l}\text { Divisions with area } \\
\text { coverage }\end{array}$} & Hill & \multicolumn{9}{l}{ Cultivated land } & Miscellaneous Land \\
\cline { 3 - 7 } & & HL & MHL & M LL & LL & VLL & Total & \\
\hline Chittagong (\%) & $4 \mathrm{I}$ & 4 & 23 & 8 & 3 & I & 90 & 10 \\
Barisal (\%) & - & 2 & 5 & 5 & I & 0 & 63 & 37 \\
Rangpur (\%) & - & 39 & 40 & 5 & I & 0 & 85 & 15 \\
Sylhet (\%) & II & 6 & 20 & 19 & 20 & II & 76 & 24 \\
\hline
\end{tabular}

Source: ${ }^{7}$

\section{Factors responsible for the variation of the yield of winter vegetables}

\section{Environmental factors}

Light, temperature, water, and soil-greatly influence plant growth and geographic distribution..$^{30}$ These factors determine the suitability of a crop for a particular location, cropping pattern, management practices, and levels of inputs needed. ${ }^{31}$ A crop performs best and is least costly to produce if it is grown under the most favourable environmental conditions. To maximize the production of any crop, it is important to understand how these environmental factors affect plant growth and development. ${ }^{19}$ Light Sunlight is essential for any crop. Dry matter production often increases in direct proportion to increasing amounts of light. ${ }^{32}$ The amount of sunlight received by plants in a particular region is affected by the intensity of the incoming light and the day length.

\section{Effects of light}

The light intensity changes with elevation, latitude, and season, as well as other factors such as clouds, dust, smoke, or fog. The total amount of light received by a crop plant is also affected by cropping systems and crop density. ${ }^{4}$ Different plants differ in their light requirements. Sunlight is essential for any crop. Dry matter production often increases in direct proportion to increasing amounts of light..$^{33}$ The amount of sunlight received by plants in a particular region is affected by the intensity of the incoming light and the day length. ${ }^{29}$ The light intensity changes with elevation, latitude, and season, as well as other factors such as clouds, dust, smoke, or fog. ${ }^{2}$ The total amount of light received by a crop plant is also affected by cropping systems and crop density. Different plants differ in their light requirements: plants thrive in full sun but grow poorly in shade, plants will produce an edible crop when grown in a shady location. However, these plants need at least $50-80 \%$ of full $\operatorname{sun}^{34}$ and plants thrive in $30-$ $50 \%$ of full sun but weaken in full sun. ${ }^{35}$ Shading sometimes is used to inhibit pigment development in crops in which the lack of colour is an important quality factor. Due to the tilt of the earth's axis and its travel around the sun, the day length varies with season and latitude. ${ }^{36}$ Photoperiod controls flowering or the formation of storage organs in some species.

\section{Effects of temperature}

Temperature influences photosynthesis, water and nutrient absorption, transpiration, respiration, and enzyme activity. These factors govern germination, flowering, pollen viability, fruit set, rates of maturation and senescence, yield, quality, harvest duration, and shelf life. ${ }^{37}$ Different plants have different temperature requirements. However, for most crop species, optimum temperatures usually range around $25^{\circ} \mathrm{C} .{ }^{38}$ Temperature requirements (usually based on night temperature) of plants are given below by the cardinal values and derived range for "effective growth" (growth range) and "optimum growth" (optimum range). Depending on the situation and the specific crop, ambient temperatures higher or lower than the effective growth range will reduce growth and delay development, and subsequently decrease yield and quality. ${ }^{39}$ The extremes may be considered killing frosts at about $0^{\circ} \mathrm{C}$ and death by heat and desiccation at about $40^{\circ} \mathrm{C}$.

\section{Effects of water}

Water is absolutely essential for winter vegetables. Vegetables can be grown according to their natural habitats with respect to water supply like Hydrophytes are plants that are adapted to living in water or in soil saturated with water. ${ }^{29}$ The hydrophytes usually have large interconnected intercellular gas-filled spaces in their root and shoot tissues to facilitate air exchange. ${ }^{4}$ Mesophytes are the most common terrestrial plants that are adapted to neither a long wet nor a long dry environment. Depending on the extension of their root systems and other plant features, however, their water requirement varies. ${ }^{40}$ Xerophytes is plants that can endure relatively long periods of drought. The xerophytes usually have special features such as reduced permeability to decrease water loss, swollen tissues to conserve water, or deep and extensive root systems to acquire water. ${ }^{41}$ Water is crucial for vegetable productivity and quality. However, water requirements of vegetable differ according to vegetable and soil types. Water needs of a plant include the water the crop uses by itself and also the losses due to evapotranspiration, water supply, land management, and water leaching at the time of the crop growth period. ${ }^{39}$

\section{Effects of drought}

Drought means a period without required rainfall or soil moisture. Droughts may lead to vegetable water scarcity and development may be stuck. It generally happens when the water content of the soil is fewer than $50 \%$ of field capacity. The main symptoms of Drought are wilting, fatigued, twisting of leaves; or browning of shoot tips. ${ }^{42}$ Among the Mesophytes, there is a variation of the impact of drought stress like the species, variety, extent and existing time, and the growth of vegetable. 


\section{Effects of flooding}

Flooding occurs when water enters soil sooner than its drainage out. Heavy rainfall, overflow of the river, enhancing run-off, extended irrigation, and poor drainage cause flooding in lowland regions. ${ }^{43}$ Under waterlogged conditions, the plant cannot be grown as a regular basis due to retard respiration. ${ }^{44}$ Oxygen deficiency in the soil causes poor growth or the death of the plant. The extent of flooding damage depends upon the species or variety, stage of vegetable development, and the type of microorganisms' attendance. High temperatures usually accelerate the damaging effects. ${ }^{1}$

\section{Effects of soil (edaphic) factors}

The soil is an important medium which supplies mineral nutrients and moisture for growth of the plant. It comprises of water, organic matter, mineral, and air. These elements actually show soil properties such as soil type, soil $\mathrm{pH}$, and fertility. ${ }^{45}$ The soil consists of various elements like sand $(0.05$ to $2 \mathrm{~mm})$, silt $(0.002$ to $0.05 \mathrm{~mm})$, and clay $(<0.002 \mathrm{~mm}) .^{46}$ The ratio of these determines soil types, such as clay, clayey loam, loam, sandy loam, and sand. Loam is composed of sand, silt, and clay in relatively even amounts, and exerts a greater influence on soil properties than does sand, silt, or clay. Soil type determines the soil's capacity to store water and nutrients, aeration, drainage, and ease of field operations. Sandy soils are easily tilled, well-drained and aerated but usually have low fertility and water-holding capacity. ${ }^{42}$ Clayey soils, on the other hand, are more fertile and have high water retention but are poorly drained and aerated. In Bangladesh, production of vegetables is more in winter seasons compare to the summer seasons. ${ }^{47}$ In summer seasons vegetable productions are less than winter. ${ }^{12}$ Winter season produce more vegetables and provides our needs. Average production of winter vegetables is depending on the environment. Winter season is favourable for vegetable production (Table 4).

Table 4 Average winter vegetable production in total land

\begin{tabular}{lllllll}
\hline \multicolumn{2}{c}{ 2013-2014 } & \multicolumn{5}{c}{ 2014-2015 } \\
\hline $\begin{array}{l}\text { Area } \\
\text { acres }\end{array}$ & Yield per Acres, kg & $\begin{array}{l}\text { Production } \\
\text { MT }\end{array}$ & $\begin{array}{l}\text { Area } \\
\text { Acres }\end{array}$ & Yield per Acres, kg & $\begin{array}{l}\text { Production } \\
\text { MT }\end{array}$ \\
\hline Total & 495510 & 3926 & 1945497 & 529023 & 4147 & 2193920
\end{tabular}

Source: ${ }^{7}$

\section{Effects of soil pH}

Soil $\mathrm{pH}$ is a measure of the soil's acidity or alkalinity, and it affects the vegetables indirectly by influencing the availability of nutrients and the activity of microorganisms. Nutrients are most available at $\mathrm{pH}$ levels between 6.5 and 7.5.8 Nutrients in the soil may be chemically tied up or bound to soil particles and unavailable to plants if the $\mathrm{pH}$ is outside this range. Individual vegetables have $\mathrm{pH}$ preferences and grow best if planted in soils that satisfy their $\mathrm{pH}$ requirements. ${ }^{45}$

\section{Effects of soil fertility}

Soil fertility is the inherent capacity of the soil to provide nutrients in adequate amounts and in proper balance for the growth of specific winter vegetables. ${ }^{45} \mathrm{~A}$ fertile soil is usually rich in nitrogen, phosphorus, and potassium, and contains sufficient trace elements and soil organic matter that improves soil structure and soil moisture retention. ${ }^{48}$

\section{Effects of soil salinity}

Soil salinity refers to the presence of excess salts in soil water, which often results from irrigated agriculture. After the plants take up the water, the dissolved salts from an irrigated water start to accumulate in the soil. Soil salinity is usually measured as electrical conductivity (EC) of the soil solution, and expressed in deci siemens per meter $(\mathrm{dS} / \mathrm{m}) .{ }^{16}$ Excess salts generally affect vegetable growth by increasing osmotic tension in the soil, making it more difficult for the plants to take up water. Excessive uptake of salts from the soil by vegetable plant also may have a direct toxic effect on the vegetables. ${ }^{49}$ Soil salinity is most pronounced in arid areas (Table 5).
Table $\mathbf{5}$ Salt tolerance of vegetable crops as determined by soil salinity (ECe)

\begin{tabular}{lll}
\hline \multirow{2}{*}{ Vegetable } & Soil & \\
\cline { 2 - 3 } & $\begin{array}{l}\text { Threshold I } \\
\left(\mathbf{d S m}^{-1}\right)\end{array}$ & $\begin{array}{l}\text { Slope Threshold } \\
\mathbf{2}\left(\mathbf{d S m}^{-1}\right)\end{array}$ \\
\hline Asparagus & 4.1 & 2 \\
Bean & $\mathrm{I}$ & 19 \\
Broccoli & 2.8 & 9.2 \\
Carrot & $\mathrm{I}$ & 14 \\
cauliflower & - & - \\
eggplant & 1.1 & 6.9 \\
lattuce & 2 & 13 \\
potato & 1.7 & 12 \\
tomato & 2.5 & 9.9 \\
\hline
\end{tabular}

Source: ${ }^{7}$

If the salt sensitive plant is grown on saline soils, plant injury can occur. Saline soil damages growth of vegetable plant, stunted plant height, wilting and in several cases plant death. Because the saline sensitive plant is less able to uptake water from the saline soil and can be fall under water stress. In coastal $70 \%$ area of Bangladesh are affected by saline soil. ${ }^{7}$ The vegetable cannot grow in a coastal area particularly winter vegetables because all of the winter vegetables are saline sensitive but some can be grown in at the minimum range of 
saline soil mostly root vegetables such as carrots, onion, sweet potato etc. ${ }^{50}$ There are different types of land in Bangladesh such as High Land (HL), Medium High Land (MHL), Medium Low Land (MLL), Low Land (LL), Very Low Land (VLL) and different types of soil such as saline, calcareous, non-calcareous, peat, floodplain, and acid soil. ${ }^{45}$ The vegetable can be grown in all types of soil but the acid soil is harmful to vegetable productions. Winter vegetables can be tolerated by mineral acidity. Not all plants respond to salinity in a similar manner; some crops can produce acceptable yields at much higher soil salinity than others. ${ }^{48}$ This is because some crops are better able to make the osmotic adjustments, enabling them to extract more water from saline soil. For example, turnip and carrot are among the most sensitive vegetables and can tolerate soil salinities of only about $1 \mathrm{dS} / \mathrm{m}$ before yield declines. Zucchini, on the other hand, can tolerate soil salinity of up to $4.7 \mathrm{dS} / \mathrm{m}$ before yield reduces. ${ }^{24}$ The ability of a crop to adjust to salinity is extremely useful. In areas where a buildup of soil salinity cannot be controlled, an alternative crop can be selected that is both more tolerant of the expected soil salinity and able to produce economic yields.

\section{Conclusion}

This study analyzes the soil and environmental conditions around the globe and searches literature according to the purpose of the study. The aim of this research is to explore the responsible factors of soil and environment for yield variation of winter vegetables. It reveals that there is a great impact of soil and environment on winter vegetable productions. Though fertilization has a great impact on winter vegetable production at a certain level but a number of edaphic factors such as soil type, soil pH, soil fertility, and soil salinity and environmental factors such as light, temperature, humidity, drought and flooding are responsible for the variation of the yield of winter vegetable production. Awareness and knowledge dissemination about the effects of soil and environmental factors at the farmers level is necessary for maximum yield of winter vegetables.

\section{Acknowledgements}

None.

\section{Conflict of interest}

Author declares that there in none of the conflicts.

\section{References}

1. Charrier G, Ngao J, Saudreau M, et al. Effects of environmental factors and management practices on microclimate, winter physiology, and frost resistance in trees. Front Plant Sci. 2015;6:259.

2. Comas LH, Bauerle TL, Eissenstat DM. Biological and environmental factors controlling root dynamics and function: effects of root ageing and soil moisture. Aust J Grape Wine Res. 2010;16(s1):131-137.

3. Hartz TK. Vegetable production best management practices to minimize nutrient loss. Horttechnology. 2006;16(3):398-403.

4. Sharmin E, Zafar F, Akram D, et al. Recent advances in vegetable oils based environment friendly coatings: A review. Ind Crops Prod. 2015;76:215-229.

5. Sarker MNI. Knowledge, Adoption and Constraint analysis of Chilli Technology in Char Area of Bangladesh. Int $J$ Ecol Dev Res. 2016;1(1):16-18.

6. Akter A, Hoque F, Zafar A, et al. Financial Analysis of Winter Vegetables Production in a Selected Area of Brahmanbaria District in Bangladesh.
Int Res J Agric Food Sci. 2016;1(6):120-127.

7. BBS. Yearbook of Agricultural Statistics-2015; 2016.

8. Sarker MNI. Poverty of Island Char Dwellers in Bangladesh. A farm level socio-economic analysis. Germany: Diplomica Publishing; 2016. $85 \mathrm{p}$.

9. Ben Said L, Jouini A, Klibi N, et al. Detection of extended-spectrum beta-lactamase (ESBL)-producing Enterobacteriaceae in vegetables, soil and water of the farm environment in Tunisia. Int J Food Microbiol. 2015;203:86-92.

10. Prodhan AS, Sarker MNI, Sultana A, et al. Knowledge, adoption and attitude on banana cultivation technology of the banana growers of Bangladesh. Int J Hortic Sci Ornam Plants. 2017;3:47-52.

11. Bisbis MB, Gruda N, Blanke M. Potential impacts of climate change on vegetable production and product quality-A review. J Clean Prod. 2018;170:1602-1620.

12. Akter S, Islam M, Rahman M. An economic analysis of winter vegetables production in some selected areas of Narsingdi district. J Bangladesh. 2012;9(2):241-246.

13. Busch J, Dawson D, Roelich K. Closing the low-carbon material loop using a dynamic whole system approach. J Clean Prod. 2017; 149:751-761

14. Sarker MNI, Kashem MA, Rahman MZ. Poverty alleviation of rural people through Chars Livelihoods Program. J Bangladesh Socioety Agric Sci Technol. 2007;4(3\&4):203-208.

15. BBS. Statistical Yearbook of Bangladesh. Bangladesh; 2012. p. 1-468.

16. Machado R, Serralheiro R. Soil Salinity: Effect on Vegetable Crop Growth. Management Practices to Prevent and Mitigate Soil Salinization. Horticulturae. 2017;3(2):30.

17. Sarker MNI, Islam, Ali A, Islam S, Bari A. Feeding Behavior and Food Preference of Red Pumpkin Beetle, Aulacophora Foveicollis. Am J Plant Biol. 2016;1(1):13-17.

18. Worsley A, Wang WC, Farragher T. The associations of vegetable consumption with food mavenism, personal values, food knowledge and demographic factors. Appetite. 2016;97:29-36.

19. Sarker MNI, Barman SC, Islam M, et al. Role of lemon (Citrus limon) production on livelihoods of rural people in Bangladesh. J Agric Econ Rural Dev. 2017;2(1):167-175.

20. AVRDC. Vegetable Production Training Manual. 1990.

21. Sarker MNI. Role of Banks on Agricultural Development in Bangladesh. Int J Ecol Dev Res. 2016;1(1):10-15.

22. Sarker MNI, Sultana A. An Investigation into the Status of Riverbank (Char) Women Dwellers in Bangladesh. Int J Rural Dev Environ Heal Res. 2017;1(1):86-92.

23. Pascale SD, Barbieri G. Effects of soil salinity from long-term irrigation with saline-sodic water on yield and quality of winter vegetable crops. Sci Hortic. 1995;64(3):145-157.

24. Liu GD, Simonne EH, Hochmuth GJJ. Soil and Fertilizer Management for Vegetable Production in Florida. UF/IFAS. 2015:3-15.

25. Minh VQ, Tri LQ. Rice soil fertility classification and constraints in the Mekong Delta. Int J Environ Rural Dev. 2010;1(1):91-97.

26. Bandyopadhyay KK, Praharaj CS, Shankaranarayanan K, et al. Amelioration of soil related constraints for improving extra long staple cotton production. Central Institute for Cotton Research. Coimbatore; 2007.

27. Re Z, Zhang M, Wilso MJ. Chemical soil constraints to crop production 
on chinese red soils. In: Al MW, Zhenli He, Xiaoe Yang, editors. The Red Soils of China. Klmver Academic Publishers; 2004:103-104.

28. Augustsson A, Uddh-Söderberg T, Filipsson M, et al. Challenges in assessing the health risks of consuming vegetables in metal-contaminated environments. Environ Int. 2018;113:269-280.

29. Liang H, Hu K, Batchelor WD, et al. Developing a water and nitrogen management model for greenhouse vegetable production in China: Sensitivity analysis and evaluation. Ecol Modell. 2018;367:24-33.

30. ALS Association. Environmental Factors. 2014

31. Yang Y, Chen W, Wang M, et al. Regional accumulation characteristics of cadmium in vegetables: Influencing factors, transfer model and indication of soil threshold content. Environ Pollut. 2016;219:1036-1043.

32. Ali MA, Islam MS, Sarker MNI, et al. Study on Biology of Red Pumpkin Beetle in Sweet Gourd Plants. Int J Appl Res J. 2015;2(1):1-4.

33. Haider MK, Islam MS, Islam SS, et al. Determination of crop coefficient for transplanted Aman rice. Int J Nat Soc Sci. 2015;2(23):34-40.

34. Liu D, Tong C. Bacterial community diversity of traditional fermented vegetables in China. LWT-Food Sci Technol. 2017;86:40-48.

35. Allemann L, Young B. Vegetable Production in a Nutshell. 2005.

36. Matschoss K, Heiskanen E. Making it experimental in several ways: The work of intermediaries in raising the ambition level in local climate initiatives. J Clean Prod. 2017;169:85-93.

37. Montri A, Biernbaum JA. Management of the Soil Environment in High Tunnels. Horttechnology. 2009;19(1):34-36.

38. Pandey R, Shubhashish K, Pandey J. Dietary intake of pollutant aerosols via vegetables influenced by atmospheric deposition and wastewater irrigation. Ecotoxicol Environ Saf. 2012;76(1):200-208.

39. Savvas D, Gianquinto G, Tuzel Y, et al. Soilless Culture. 2013.

40. Lam SK, Suter H, Davies R, et al. Direct and indirect greenhouse gas emissions from two intensive vegetable farms applied with a nitrification inhibitor. Soil Biol Biochem. 2018;116:48-51.

41. Sinesio F, Saba A, Peparaio M, et al. Capturing consumer perception of vegetable freshness in a simulated real-life taste situation. Food Res Int. 2018;105:764-771.

42. Haferkamp MR. Environmental factors affecting plant productivity. Achiev Effic Use Rangel Resour. 1988; p. 27-36.

43. Kristiansen AL, Bjelland M, Himberg-Sundet A, et al. Associations between sociocultural home environmental factors and vegetable consumption among Norwegian 3-5-year olds: BRA-study. Appetite. $2017 ; 117: 310-320$

44. Felix J, Doohan DJ, Bruins D. Differential vegetable crop responses to mesotrione soil residues a year after application. Crop Prot. 2007;26(9):1395-1403

45. Xie T, Cui B, Bai J, et al. Rethinking the role of edaphic condition in halophyte vegetation degradation on salt marshes due to coastal defense structure. Phys Chem Earth, Parts. 2016;103:81-90.

46. Anderson E, Johnson P. Soil Management for Potatoes. 2012.

47. Sarker MNI, Ali MA, Islam MS. Causes and possible solutions of poverty perceived by char dwellers in Bangladesh. Int $J$ Nat Soc Sci. 2015;2(21):37-41.

48. Monier E-GAM, Amer WM. Soil-vegetation relationships in a coastal desert plain of southern Sinai, Egypt. J Arid Environ. 2003;55(4):607628.

49. Sarker MNI. Causes and possible solutions of seasonal food insecurity (Monga) perceived by char dwellers in Bangladesh. Int J Ecol Dev Res. 2016;1(1):2-9.

50. Islam MS, Ali MA, Sarker MNI. Efficacy of medicinal plants against seed borne fungi of wheat seeds. Int J Nat Soc Sci. 2015;2(21):48-52. 